\title{
Ефективність антикоагулянтної терапії у паціентів із гострим тромбозом глибоких вен нижніх кінцівок
}

\begin{abstract}
Мета роботи: оцінити ризик рецидиву ТГВ, шляхом визначення ступеня реканалізації тромба та значення рівня D-димеру на момент закінчення антикоагулянтного лікування.

Матеріали і методи. Обстежено та проліковано 98 пацієнтів з тромбозом глибоких вен (ТГВ) різної локалізації. Пацієнтів спостерігали в період антикоагулянтної терапії (n-98) та після її проведення (n-76) в терміни від 7 до 120 місяців. Залежно від схеми антикоагулянтної терапії пацієнти були поділені на три групи: перша група (32) отримували варфарин, друга група (34) - ривароксабан, третя (32) - дабігатран етексилат. Усіх пацієнтам з метою верифікації діагнозу і моніторингу якості терапії проводили ультрасонографічне дослідження та оцінювали рівень D-димеру в крові.

Результати досліджень та їх обговорення. Більшість пацієнтів з ТГВ не потребувала подовженої антикоагулянтної терапії. В терміни початкової та тривалої антикоагуляції, незалежно від вибору схеми лікування, рецидиву ТГВ або випадків ТЕЛА ми не спостерігали. У пацієнтів всіх груп, після закінчення лікування, найчастіше спостерігались рецидиви ТГВ впродовж першого року. Загалом, протягом всього терміну спостереження, частота рецидивів серед пацієнтів першої групи склала 10 випадків, другої групи 4 випадки, третьої - три (р<0,05). Між пацієнтами, які приймали ривароксабан і дабігатрану етексилат, не спостерігалося достовірної різниці у частоті рецидивів тромбозу, тоді як між групою пацієнтів, які отримували варфарин, та другою і третьою групами різниця була достовірна (p<0,05). До кінця терміну лікування хворих з ТГВ позитивні результати відновлення прохідності вен та значення рівня D-димеру < 500 нг/мл були виявлені у 2 раза частіше у пацієнтів, що приймали новітні оральні антикоагулянти (НОАК). Це і пояснює, на нашу думку, низький відсоток рецедиву у другій та третій групах порівняно з першою групою, де пацієнти приймали АВК.

Підвищений рівень D-димеру в крові >500 нг/мл на момент завершення антикоагулянтної терапії є фактором ризику рецидиву у пацієнтів із ТГВ, як і залишкова непрохідність вен. Тривала антикоагуляція варфарином є найменш прогнозованою щодо ризику рецидиву ТГВ (р<0,05), тоді як при застосуванні ривароксабану і дабігатрану етексилату не спостерігалося достовірної різниці у частоті рецидивів ТГВ.
\end{abstract}

Ключові слова: тромбоз глибоких вен; антикоагулянтна терапія; рецидив; D-димер; залишкова непрохідність вен.

Постановка проблеми і аналіз останніх досліджень та публікацій. Тривалість антикоагулянтної терапії у пацієнтів із вперше діагностованим неспровокованим ТГВ є одним 3 найбільш суперечливих питань у лікуванні даного захворювання [1]. Останні дослідження рекомендують проводити лікування ТГВ щонайменше впродовж трьох місяців, оскільки показник рецидиву вищий в перші кілька місяців після симптоматичного ТГВ [2]. Після перших трьох місяців, American College of Chest Physicians (ACCP) рекомендує індивідуальну оцінку можливого рецидиву ТГВ шляхом співвідношення ризику та користі при тривалій антикоагулянтній терапії у пацієнтів із не спровокованим ТГВ. Ризик рецидиву потрібно збалансувати з ризиком виникнення кровотечі та можливої тяжкості цих тромботичних та геморагічних подій [3].

У пацієнтів з ТГВ, спричинених тимчасовим фактором ризику, після його усунення, ризик пізнього рецидиву вважається достатньо низьким, та не вимагає продовження лікування. Однак ризик рецидиву, пов'язаний із спровокованим ТГВ, різниться у різних дослідженнях [4]. У хворих, в яких ТГВ був спровокований тимчасовими факторами ризику, таким, як хірургія або травма, ризик рецидиву є низьким $<3 \%$. Частота рецидивів не спровокованих ТГВ після відміни антикоагулянтної терапії складає 10 \% після першого року та досягнувши $30 \%$ через 5 років [5].

В останні роки докладаються значні зусилля для виявлення клінічних та лабораторних показників, здатних стратифікувати ризик рецидиву у пацієнтів із першим епізодом ТГВ. Спадкові тромбофілії, рівні факторів згортання, D-димер, наявність залишкового тромба, серед ряду інших факторів були оцінені ізольовано або як частина балів для керування прийняттям клінічних рішень для цих пацієнтів. Показано, що D-димер та залишкова венозна непрохідність (ЗВН) є маркерами прогнозування ризику, які можуть допомогти адаптувати тривалість антикоагуляції після першого епізоду тромбозу [6]. Так, у дослідженні PROLONG показано, що підвищений постантикоагуляційний D-димер асоціюється із зростанням ризику рецидиву після не спровокованого ТГВ, проте пацієнтів із спровокованим ТГВ у даному дослідженні не враховували [7]. Діагности- 


\section{З ДОСВІДУ РОБОТИ}

ку залишкової непрохідності вен було розроблено з метою адаптації тривалості антикоагулянтної терапії у двох дослідженнях - DACUS та AESOPUS. Перше дослідження показало, що діагностика залишкової непрохідності вен передбачала розвиток рецидиву як після не спровокованого, так і після спровокованого ТГВ, тоді як дослідження AESOPUS доводить більш значні переваги пролонгування антикоагулянтної терапії після не спровокованого тромбозу на грунті стійкої залишкової оклюзії вен $[8,9]$.

Ми прагнули визначити, чи асоціюється 3ВН та значення D-димеру з підвищеним ризиком рецидиву у пацієнтів з ТГВ, які припинили антикоагулянтну терапію, базуючись на результатах даних власних досліджень.

Мета роботи: оцінити ризику рецидиву ТГВ, шляхом визначення ступеня реканалізації тромба та значення рівня D-димеру на момент закінчення антикоагулянтного лікування.

Матеріали і методи. Ми виконали клінічні, лабораторні та інструментальні дослідження і хірургічне лікування 98 хворих на тромбоз глибоких вен нижніх кінцівок різної локалізації, які знаходилися на стаціонарному лікуванні в клініці кафедри хірургії № 1 Івано-Франківського національного медичного університету.

У 60 (61,2 \%) пацієнтів тромбоз глибоких вен розцінювали як спровокований: впродовж останнього місяця у них виникали стани, які зумовлювали погіршення гемодинаміки у глибоких венах нижніх кінцівок. У 38 (38,8 \%) пацієнтів в анамнезі не було факторів, які могли спричинити тромбоз глибоких вен, тому його розцінювали як не спровокований. Дистальний тромбоз глибоких вен діагностовано у 28 (28,6 \%) пацієнтів, причому у 19 (19,4 \%) з них він був спровокований, і тільки у 9 (9,9 \%) випадках не вдалося встановити його причину.

Всі хворі були розподілені на три групи залежно від особливостей антикоагулянтної терапії ТГВ. Першу групу сформували 32 пацієнтів, у яких як антикоагулянтну терапію застосовували варфарин 5 мг одноразово ввечері на фоні призначення низькомолекулярних гепаринів (НМГ) в дозі 0,1 мл на 10 кг маси тіла хворого двічі в добу. Підбір дози непрямих антикоагулянтів проводили під контролем МНВ, низькомолекулярні гепарини відміняли, коли цей показник дорівнював або перевищував 2. Середні терміни підбору дози варфарину складали $(6,3 \pm 0,8)$ діб. Тридцять чотири пацієнти сформували другу дослідну групу. У них застосовували ривароксабан у дозі 15 мг двічі на добу перорально впродовж перших трьох тиж- нів, далі по 20 мг на добу продовжували до трьох чи шести місяців лікування. Третю дослідну групу сформували 32 пацієнтів, в яких лікування ТГВ проводили введенням НМГ дозі 0,1 мл на 10 кг маси тіла хворого впродовж 5 діб, з шостої доби пацієнтам призначали дабігатрану етексилат у дозі 150 мг перорально двічі в добу.

У всіх пацієнтів з метою верифікації діагнозу і моніторингу якості терапії проводили компресійне ультрасонографічне дослідження в В-режимі на час госпіталізації в стаціонар, на 5, 10, 30, 60 і 90 доби лікування. Цей метод вважали найбільш інформативним для діагностики та проводили його у три етапи: компресія глибоких вен, двовимірне сканування та кольорове дуплексне картування. В динаміці лікування хворих на тромбоз глибоких вен детально проводили моніторинг розмірів лізису тромба, тобто визначали ступінь реканалізації i, відповідно, якість і швидкість відновлення інтравенозного кровотоку.

Оцінювали рівень D-димеру в крові за імунохроматографічним методом на час госпіталізації в стаціонар, на 30, 60, 90 доби спостереження.

Пацієнтів спостерігали в період антикоагулянтної терапії (n-98) та після іï̈ проведення (n-76) в терміни від 7 до 120 місяців.

\section{Результати досліджень та їх обговорення.} Більшість пацієнтів з ТГВ не потребували подовженої антикоагулянтної терапії. В терміни початкової та тривалої антикоагуляції, незалежно від вибору схеми лікування, рецидиву ТГВ або випадків ТЕЛА ми не спостерігали. У пацієнтів всіх груп, після закінчення лікування, найчастіше спостерігались рецидиви ТГВ впродовж першого року. Загалом, протягом всього терміну спостереження, частота рецидивів серед пацієнтів першої групи склала 10 випадків, другої групи 4 випадки, третьої - три $(\mathrm{p}<0,05)$. Між пацієнтами, які приймали ривароксабан і дабігатрану етексилат, не спостерігалося достовірної різниці у частоті рецидивів тромбозу, тоді як між групою пацієнтів, які отримували варфарин, та другою і третьою групами різниця була достовірною $(\mathrm{p}<0,05)$.

Серед цих 17 пацієнтів 15 мали підвищений рівень D-димеру в крові > 500 нг/мл. Чотирнадцять подій, що призвели до рецедиву тромбозу були не спровокованими, один випадок вторинний після госпіталізації внаслідок серцевої недостатності та двоє вторинних після хірургічних втручань. Частота рецидивів була вищою у чоловіків 11 (64,7 \%), ніж у жінок 6 (35,3 \%).

В останній день завершення антикоагулянтної терапії виконували компресійну ультрасоно- 
графію нижніх кінцівок. Загальну стегнову, стегнову, підколінну вени та вени гомілки оцінювали двосторонньо, а наявність залишкового венозного тромба визначали 4-ступеневою градацією: оклюзія - відсутність кровотоку у вені, слабка - при компресії ультразвуковим датчиком просвіт вени стискається не більше як на 30 \%, средня - просвіт вени стискається не більше як на 50 \%, добра - вена стискається більше як на 70 \%.

Встановлено, що через 30 днів лікування антикоагулянтами кількість пацієнтів, в яких зберігалася оклюзія венозного русла, а також значення показників зі слабкою та середньою ступенем реканалізації, в трьох дослідних групах статистично значимо не відрізнялася. Через 3 місяці на фоні адекватного лікування добрі результати були досягнуті у другій групі: у жодного пацієнта не діагностовано повної оклюзії, кількість пацієнтів 3 середнім ступенем реканалізації була максимальною. Добра реканалізація на даному етапі спостерігалась у 24 (75 \%) пацієнтів 3 групи.

Через 6 місяців та один рік на фоні антикоагулянтної терапії відсоток оклюзії у першій групі був значно вищим, ніж у другій і третій групах $(\mathrm{p}<0,05)$. Потрібно зазначити, що у другій та третій групах не зустрічались пацієнти 3 оклюзією чи слабкою реканалізацією, відсоток хворих
3 доброю реканалізацією у другій групі був максимальним $(\mathrm{p}<0,05)$.

Таким чином, до кінця терміну лікування хворих з ТГВ позитивні результати відновлення прохідності вен та значення рівня D-димеру $<500$ нг/мл - були виявлені у 2 раза частіше у пацієнтів, що приймали новітні оральні антикоагулянти (НОAК). Це і пояснює, на нашу думку, низький відсоток рецидиву у другій та третій групах порівняно з першою групою, де пацієнти приймали антагоніст вітаміну K.

Висновки. 1. Підвищений рівень D-димеру в крові $>500$ нг/мл на момент завершення антикоагулянтної терапії $€$ фактором ризику рецидиву у пацієнтів із ТГВ, як і залишкова непрохідність вен.

2. У пацієнтів, які приймали АВК, ризик рецидиву після відміни був вищим ніж у групі пацієнтів, які отримували НОАК, що зумовлено відсутністю повної реканалізації глибоких вен у пацієнтів першої групи.

3. Для визначення тривалості призначення антикоагулянтної терапії та для профілактики рецидиву ТГВ необхідно застосовувати індивідуальний підхід, базуючись на даних анамнезу, інструментальних та лабораторних методах досліджень.

\section{СПИСОК ЛІТЕРАТУРИ}

1. Гудз I. М. Проблеми рецидиву тромбозу глибоких вен нижніх кінцівок у світлі доказової медицини / I. М. Гудз, О. І. Гудз // Галицький лікарський вісник. - 2016. - Т. 3, № 3 (частина 1). - C. 72-74.

2. Duration of anticoagulant therapy after a first episode of an unprovoked pulmonary embolus or deep vein thrombosis: Guidance from the SSC of the ISTH / T. Baglin, K. Bauer, J. Douketis [et al.] // J. Thromb. Haemost. - 2012. - Vol. 10. P. 698-702.

3. Antithrombotic therapy for VTE disease: CHEST guideline and expert panel report / C. Kearon, E. A. Akl, J. Ornelas [et al.] // Chest. - 2016. - Vol. 149. - P. 315-52.

4. Risk of recurrence after a first episode of symptomatic venous thromboembolism provoked by a transient risk factor: a systematic review / A. Iorio, C. Kearon, E. Filippucci [et al.] // Arch. Intern. Med. - 2010. - Vol. 170. - P. 1710-1716.

5. The long-term recurrence risk of patients with unprovoked venous thromboembolism: an observational cohort study / P. A. Kyrle, M. Kammer, L. Eischer [et al.] // J. Thromb. Haemost. - 2016. - Vol. 14. - P. 2402-2409.

6. Long term risk of recurrence in patients with a first unprovoked venous thromboembolism managed according to D-dimer results; a cohort study / C. Kearon, S. Parpia, F. A. Spencer [et al.] // Journal of Thrombosis and Haemostasis. - 2019. -(17). - P. 144-1152.

7. PROLONG Investigators (on behalf of Italian Federation of Anticoagulation Clinics). Lsefulness of repeated D-dimer testing after stopping anticoagulation for a first episode of unprovoked $\mathrm{v}$ venous thromboembolism: the PROLONG II prospective study / B. Cosmi, C. Legnani, A. Tosetto [et al.] // Blood. - 2010. Vol. 15. - P. 481-488.

8. Residual vein thrombosis to establish duration of anticoagulation after a first episode of deep vein thrombosis: the Duration of Anticoagulation based on Compression UltraSonography (DACUS) Study / S. Siragusa, A. Malato, R. Anastasio [et al.] // Blood. - 2008. - Vol. 112 (3). - P. 511-515.

9. AESOPUS Investigators. Residual thrombosis on ultrasonography to guide the duration of anticoagulation in patients with deep venous thrombosis: a randomized trial / P. Prandoni, M. H. Prins, A. W. Lensing [et al.] // Ann. Intern. Med. - 2009. - Vol. 150. - P. 577-585. 


\section{REFERENCES}

1. Hudz, I.M., \& Hudz, O.I. (2016). Problemy retsedyvu trombozu hlybokykh ven nyzhnikh kintsivok u svitli dokazovoi medytsyny [Problems of thrombosis recurrence of deep veins of lower extremities in the light of evidence-based medicine]. Halytskyi likarskyi visnyk - Galician Doctor's Bulletin, 3 (3) (part1), 72-74 [in Ukrainian].

2. Baglin, T., Bauer, K., Douketis, J., Buller, H., Srivastava, A., \& Johnson, G., et al. (2012). Duration of anticoagulant therapy after a first episode of an unprovoked pulmonary embolus or deep vein thrombosis: Guidance from the SSC of the ISTH. J. Thromb. Haemost., 10, 698-702.

3. Kearon, C., Akl, E.A., \& Ornelas, J. (2016). Antithrombotic therapy for VTE disease: CHEST guideline and expert panel report. Chest, 149, 315-352.

4. Iorio, A., Kearon, C., \& Filippucci, E. (2010). Risk of recurrence after a first episode of symptomatic venous thromboembolism provoked by a transient risk factor: a systematic review. Arch. Intern. Med., 170, 1710-1716.

5. Kyrle, P.A., Kammer, M., \& Eischer, L. (2016). The longterm recurrence risk of patients with unprovoked venous thromboembolism: an observational cohort study. J. Thromb. Haemost., 14, 2402-2409.

Електронна адреса для листування: klymyuk_v@ukr.net
6. Kearon, C., Parpia, S., Spencer, F.A., Schulman, S., Stevens, S.M., Shah, V., Bauer, K.A., Douketis, J.D., Lentz, S.R., Kessler, C.M., \& Connors, J.M. (2019). Long term risk of recurrence in patients with a first unprovoked venous thromboembolism managed according to D-dimer results; a cohort study. Journal of Thrombosis and Haemostasis, (17), 1144-1152.

7. Cosmi, B., Legnani, C., \& Tosetto, A. (2010). PROLONG Investigators (on behalf of Italian Federation of Anticoagulation Clinics). Lsefulness of repeated D-dimer testing after stopping anticoagulation for a first episode of unprovoked $\mathrm{v}$ venous thromboembolism: the PROLONG II prospective study. Blood, 115, 481-488.

8. Siragusa, S., Malato, A., \& Anastasio, R. (2008). Residual vein thrombosis to establish duration of anticoagulation after a first episode of deep vein thrombosis: the Duration of Anticoagulation based on Compression UltraSonography (DACUS) study. Blood, 112 (3), 511-515.

9. Prandoni, P., Prins, M.H., \& Lensing, A.W. (2009). AESOPUS Investigators. Residual thrombosis on ultrasonography to guide the duration of anticoagulation in patients with deep venous thrombosis: a randomized trial. Ann. Intern. Med., 150, 577-585.

Отримано 14.11.2019

\title{
S. M. VASYLIUK, V. M. ATAMANIUK
}

Ivano-Frankivsk National Medical University

\section{ANTICOAGULATION EFFICACY IN PATIENTS WITH ACUTE DEEP VEIN THROMBOSIS OF THE LOWER EXTREMITIES}

\begin{abstract}
The aim of the work: to estimate the risk of deep vein thrombosis (DVT) recurrence by determining the degree of residual vein obstruction and the value of the D-dimer level at the end of anticoagulation.

Materials and Methods. There were examined and treated 98 patients with deep vein thrombosis of various locations. Patients were observed during anticoagulation therapy (n-98) and after its performance (n-76) for between 7 and 120 months. Depending on the scheme of anticoagulation therapy patients were divided into three groups: group 1 (32) received Warfarin, group 2 (34) - Rivaroxaban, group 3 (32) - Dabigatran Etexilate. To all patients were verify the diagnosis and monitoring of the therapy, ultrasonographic examination was conducted and evaluated the D-dimer levels.

Results and Discussion. In terms of initial and long-term anticoagulant therapy, regardless of the choice of treatment regimens, DVT recurrence or pulmonary embolism cases we did not observed. After the treatment, during the first year, recurrence of DVT was more frequent in patients of all groups. In patients of the group 1 their frequency was $(15.38 \pm 7.08) \%$, group $2-(8.7 \pm 5.88) \%$, group 3 (3.7 \pm 3.63$) \%$, which did not differ significantly $(\mathrm{p}=0.33)$. In general, the overall observation period showed a recurrence rate among the patients of group 1 was 10 cases, 4 cases in group 2, and three cases in group $3(p<0.05)$. There was no significant difference in the incidence of thrombosis recurrence was observed between patients taking Rivaroxaban and Dabigatran etexilate, whereas there was a significant difference between the 1 and 3 groups $(\mathrm{p}<0.05)$. By the end of treatment patients with DVT, positive results restoration of patency of veins and significance of D-dimer $<500 \mathrm{ng} / \mathrm{ml}$ - were detected in 2 times more often in patients receiving the novel oral anticoagulants (NOAC). This explains the low percentage of recurrence in the groups 2 and 3 compared to group 1 where patients received antagonist vitamin K. Elevated levels of D-dimer> $500 \mathrm{ng} / \mathrm{ml}$ at the time of completion of anticoagulation is a risk factor for relapse in patients with DVT, as well as residual obstruction of veins. Long-term anticoagulation with Warfarin is the least predictable as for the risk of recurrence of DVT $(\mathrm{p}<0.05)$, when the application of Rivaroxaban and Dabigatran Etexilate showed no significant difference in the incidence of DVT recurrence.
\end{abstract}

Keywords: deep vein thrombosis; anticoagulant therapy; recurrence; D-dimer; residual vein obstruction. 


\author{
С. М. ВАСИЛЮК, В. М. АТАМАНЮК
}

Ивано-Франковский национальный медицинский университет

\title{
ЭФФЕКТИВНОСТЬ АНТИКОАГУЛЯНТНОЙ ТЕРАПИИ У ПАЦИЕНТОВ С ОСТРЫМ ТРОМБОЗОМ ГЛУБОКИХ ВЕН НИЖНИХ КОНЕЧНОСТЕЙ
}

\begin{abstract}
Цель работы: оценить риск рецидива ТГВ, путем определения степени реканализации тромба и значение уровня D-димера на момент окончания антикоагулянтного лечения.

Материалы и методы. Обследовано и пролечено 98 пациентов с тромбозом глубоких вен (ТГВ) различной локализации. Пациентов наблюдали в период антикоагулянтной терапии (n-98) и после ее проведения (n-76) в сроки от 7 до 120 месяцев. В зависимости от схемы антикоагулянтной терапии пациенты были разделены на три группы: первая группа (32) получали варфарин, вторая группа (34) - ривароксабан, третья (32) - дабигатран этексилат. Всех пациентов с целью верификации диагноза и мониторинга качества терапии проводили ультрасонографические исследования и оценивали уровень D-димера в крови.

Результаты исследований и их обсуждение. Большинство пациентов с ТГВ не нуждались удлиненной антикоагулянтной терапии. В сроки начальной и длительной антикоагуляции, независимо от выбора схемы лечения, рецидива ТГВ или случаев ТЭЛА мы не наблюдали. У пациентов всех групп, после окончания лечения, чаще всего наблюдались рецидивы ТГВ в течение первого года. В общем, в течение всего срока наблюдения, частота рецидивов у пациентов первой группы составила 10 случаев, второй группы 4 случая, третьей - три (р <0,05). Между пациентами принимавших ривароксабан и дабигатрана этексилат не наблюдалось достоверной разницы в частоте рецидивов тромбоза, тогда как между группой пациентов получавших варфарин и второй и третьей группами разница была достоверной (р <0,05). K концу срока лечения больных с ТГВ положительные результаты восстановления проходимости вен и значение уровня D-димера <500 нг / мл - были обнаружены в 2 раза чаще у пациентов принимавших новейшие пероральные антикоагулянты (НОАК). Это и объясняет, по нашему мнению, низкий процент рецидивов во второй и третьей группах в сравнении с первой группой, где пациенты принимали АВК. Повышенный уровень D-димера в крови> 500 нг / мл на момент завершения антикоагулянтной терапии является фактором риска рецидива у пациентов с ТГВ, как и остаточная непроходимость вен. Длительная антикоагуляция варфарином является наименее прогнозируемой по риску рецидива ТГВ (р <0,05), тогда как при применении ривароксабана и дабигатрана этексилат не наблюдалось достоверной разницы в частоте рецидивов ТГВ.
\end{abstract}

Ключевые слова: тромбоз глубоких вен; антикоагулянтная терапия; рецидив; D-димер; остаточная непроходимость вен. 